\title{
Conceptual Design of Inventory Analysis Software to Support the Life Cycle Assessment in Palm Oil Production
}

\author{
Kiman Siregar ${ }^{1,}$, Supriyanto Supriyanto ${ }^{2}$, Devitra Saka Rani ${ }^{3}$, Yanuar Nurdiansyah ${ }^{4}$, \\ and Feri Wijayanto ${ }^{5}$ \\ ${ }^{1}$ Department of Agricultural Engineering of Syiah Kuala University, Jl.Tgk.Hasan Krueng Kalee \\ No.3 Kopelma, Banda Aceh 23111, Indonesia \\ ${ }^{2}$ Mechanical and Biosystem Engineering Department, Faculty of Agricultural Engineering and \\ Technology, IPB University, PO BOX 220 Bogor, Indonesia \\ ${ }^{3}$ Graduate School of Life and Environmental Sciences, University of Tsukuba, 1-1-1, Tennodai, \\ Tsukuba, Ibaraki 305-8577, Japan \\ ${ }^{4}$ Program Study of Information Technology, University of Jember, Jl. Kalimantan 37, Jember 68121, \\ Indonesia \\ ${ }^{5}$ Institute for Computing and Information Science, Radbound University Comenisulaan 4, \\ 6525 HP Nijmegen, The Netherlands
}

\begin{abstract}
Life cycle assessment is a quantitative method to analyze the environmental impact that consists of four main activities: goal and scope definition, life cycle inventory, life cycle impact assessment, and interpretation. The application of the life cycle in palm oil industry are very important and already conducted by many researchers. However, the most difficult task in life cycle assessment are the life cycle inventory. In this research, this study proposed the software to support the life cycle inventory in palm oil production. The result of the study was the conceptual design of the life cycle inventory software.
\end{abstract}

Keywords: Environment friendly, life cycle inventory, software, sustainable palm oil

\section{Introduction}

Palm oil is a vital product in the world to produce cooking oil, salad oil, margarine, shortening, soap, fatty acid, biodiesel, and other valuable product. Indonesia, as the biggest producer of palm oil in the world [1]. One of the concerns in the palm oil industry is the environmental aspect of achieving the sustainability of the productions. The government and industry have an action by implementing the Roundtable Sustainable Palm Oil (RSPO) and Indonesian Sustainable Palm Oil (ISPO) as a standard to prevent the environmentally damaged during the productions [2, 3]. Another effort, by utilizing the Life Cycle Assessment (LCA) based on ISO 14040 included the series of the standard [4, 5].

LCA consists of several activities such as (i) scope and definition, (ii) life cycle inventory analysis, (iii) life cycle impact assessment, and (iv) interpretation. The range of

\footnotetext{
* Corresponding author: ksiregar.chairilcan@gmail.com
} 
analysis has defined the boundary of the system included in the study. The scope included the definition of the boundary. Then, the inventory analysis is activities to collect the information on material flow, energy flow, system design, and information of the system will be analyzed.

Finally, the impact on the environment analyzed to get the result of the LCA. The users can interpret the result to get feedback on the system. In the palm oil industry, LCA implemented to analyze biodiesel production [6-10], land-use change analysis, and integrated utilizing the Palm Oil Mill Effluent (POME) for valuable product $[11,12]$. In the previous study, the inventory analyzed conducted with specific cases and specific assumptions [13]. To extend the examined with another case, the tools of the life cycle inventory to assist evaluating the LCA $[14,15]$.

This research proposed the conceptual design of the life cycle inventory software for palm oil production. The conceptual framework consists of the system boundary of the system, actor design, and user interface design on the life cycle assessment application.

\section{Materials and methods}

The development of the software to support the inventory in the palm oil industry to conduct the LCA consists of the analysis, software design, and implementation.

\subsection{Analysis}

Palm oil production consists of land preparation, cultivation, transportation, palm oil mill, and conversation to the valuable product such as biodiesel and others. The boundary of the system in this research was defined (Figure 1). In palm oil plantation the input resources were needed are seed, fertilizer, herbicide, water, and diesel. In a life cycle assessment, inventory analysis was based on the boundary of the system. Based on the boundary, data was collected to evaluate the environmental impact of palm oil production. In this research, data will evaluate and collect from the Aceh Province, Indonesia.

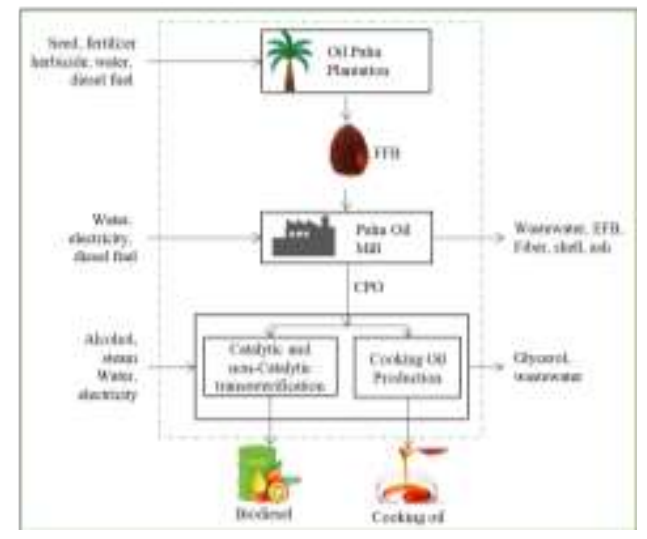

Fig. 1. Boundary condition of the system

The utilization of the resources mainly calculated in the area. Then, the Fresh Fruit Bunch (FFB) send to the palm oil mill (POM) to process the FFB to the Crude Palm Oil (CPO) $[4,15,16]$. The fiber and shell utilized to generate the energy to run the POM. The Empty Fruit Bunch (EFP) utilized as compos to use again as fertilizer. The CPO used to produce the biodiesel through transesterification process. An other products to provide the 
cooking oil. Finally, the boundary condition set regarding developing the life cycle inventory software.

\subsection{Software design}

This step, the design of Life Cycle Inventory (LCI) software was conducted by identifying the users related to the LCI Database. The data was collected from the researchers (expert) and practitioner by the software developer. Then, the data collector will collect the baseline data and input to the system. Data verification staff validates the data collected to the system. Finally, specific users will use the baseline data by information the new data with the case, edit the LCI database, and use (view) the database. Figure 2 shows the relation of the users in the database LCI.

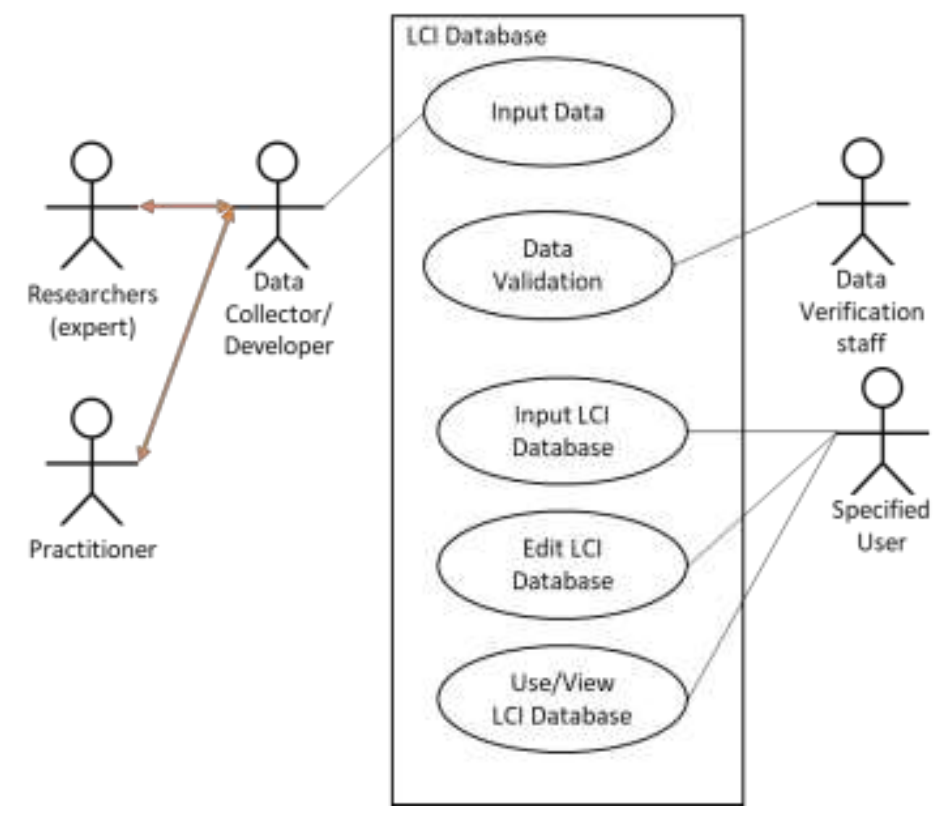

Fig. 2. Role of the users in the LCI database

\subsection{Implementation}

Software implementation was the process to transform the concept of software development. A database management system (DBMS) was implemented to store and manage the data from the inventory process. The MySQL DBMS was used to run the software. PHP and Javascript programming was used to develop the system interface. The user interface was developed to interact with the system.

\section{Results and discussion}

The result of this research was the conceptual design of the LCI software for the palm oil industry. Based on the analysis phased, the users with a specific role could access the system to input, edit, and make the new database from the cases. Then, the facility to input was designed in the user interfaces to make the system accessible to the users.

The user interface designed using the Bootstrap that consists of the Javascript, CSS, and HTML. At the beginning of the software, users should log in to the system with a specific 
username and password. The username set by the administrator to the specific user to conduct the inventory. In the main interface of the LCA, the user can access the menu to conduct the inventory analysis. The baseline dataset was input by the developers, and the user can edit the database based on specific industry conditions. On the left side, there are several menus to access the inventory analysis such as nursery, cultivation, plant maintenance, harvesting, transportation, POM, and process to biodiesel using the transesterification. The users can use the menu to access the inventory pages. The overall interface is shown in Figure 3.

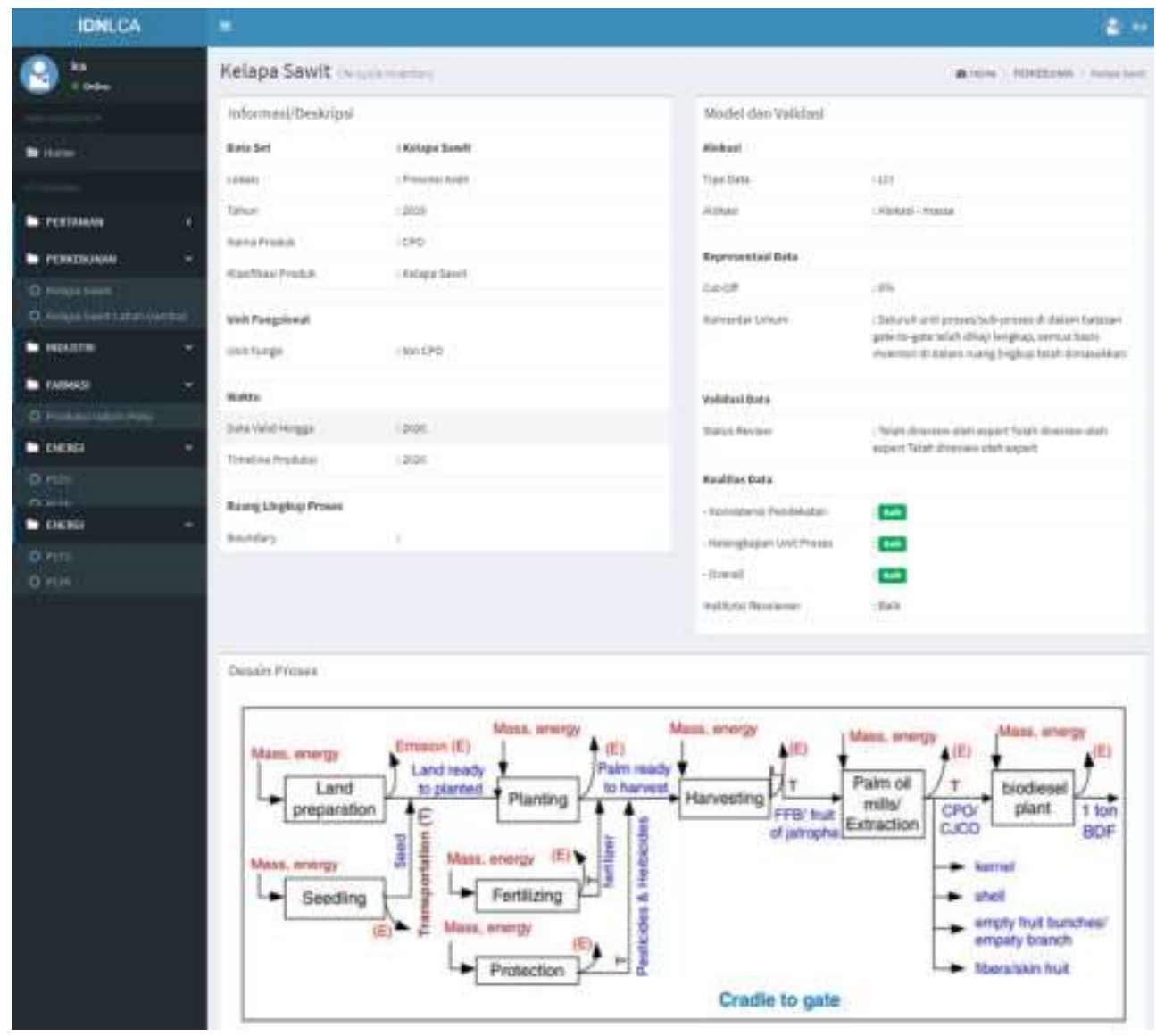

Fig. 3. The user interface of the Life-Cycle Inventory

\section{Conclusion}

The result of this study was the conceptual design of the Inventory analysis software to support the LCA of palm oil production. The software consists of the input facility, analysis, and visualizing the result of inventory. The inventory, analysis software can help to manage the data during the inventory process. 


\section{References}

1. O. Pye, World Dev., 121:218-228(2019).

https://doi.org/10.1016/j.worlddev.2018.02.014

2. L.T. Gan, H. Cap, Planter, 92:379-399(2016). http://www.isp.org.my/

3. S. Hutabarat, Agro Ekonomi. 28:170-188(2017). https://doi.org/10.22146/jae.27789

4. K. Siregar, Ichwana, I.S. Nasution, Sholihati, I. Sofiah, T. Miharza,. IOP Conference Series: Earth Environmental Science. 542:012046(2019).

https://doi.org/10.1088/1755-1315/542/1/012046

5. M. Finkbeiner, A. Inaba, R. Tan, K. Christiansen, H.-J. Klüppel, Int. J. Life Cycle Assess, 11:80-85(2006). https://doi.org/10.1065/lca2006.02.002

6. K. Siregar, A.H. Tambunan, A.K. Irwanto, S.S. Wirawan, T. Araki, A Comparison of life cycle inventory of pre-harvest, production of crude oil, and biodiesel production on Jatropha curcas and palm oil as a feedstock for biodiesel in Indonesia, (Yokohama, Japan, 2012), Proceeding of Ecobalance 2012 Conference, 21-24(2012). https://scholar.google.co.id/scholar?oi=bibs\&cluster=16053431475488963685\&btnI= $\underline{1 \& h l=e n}$

7. S.A. Archer, R.J. Murphy, R. Steinberger-Wilckens, Renew. Sustain. Energy Rev., 94:694-704(2018). https://doi.org/10.1016/j.rser.2018.05.066

8. Y. Manik, A. Halog, Integr. Environ. Assess. Manag., 9:134-141(2013). https://doi.org/10.1002/ieam.1362

9. Z. Sajid, F. Khan, Y. Zhang, Renew. Energy. 85:945-952(2016). https://doi.org/10.1016/j.renene.2015.07.046

10. K. Siregar, S. Sholiati, I. Sofiah, T.Miharza, R.H. Setyobudi, O. Anne, et al. E3S Web of Conferences 190:00021(2020). https://doi.org/10.1051/e3sconf/202019000021

11. T. Mumtaz, S. Abd-Aziz, N. Rahman, P.L. Yee, Y. Shirai, M. Hassan, African J. Biotechnol., 7,21:3900-3905(2008). https://www.ajol.info/index.php/ajb/article/view/59466

12. S. Tabassum, Y. Zhang, Z. Zhang, J. Clean. Prod., 95,148-155 (2015). https://doi.org/10.1016/j.jclepro.2015.02.056

13. R.H. Crawford, J. Environ. Manage., 88:496-506(2008). https://doi.org/10.1016/i.jenvman.2007.03.024

14. J. Winkler, B. Bilitewski, J. Waste Manag., 27:1021-1031(2007). https://doi.org/10.1016/j.wasman.2007.02.023

15. K. Siregar A.L. Machsun, S. Sholihati, R. Alamsyah, I. Ichwana, N. C. Siregar, et al., E3S Web of Conferences. 188:00018(2020). https://doi.org/10.1051/e3sconf/202018800018

16. A. Ilyana, W. Hasrulnizzam, W. Mahmood, M.H. Fazli, M. Fauadi, M. Nizam et al., Pol. J. Environ. Stud., 24,4:1463-1475(2015). http://www.pjoes.com/Author-Ilyana$\underline{\text { Abdullah/8551 }}$ 